\title{
Why I use Poetry in My Medical Teaching
}

\author{
Dr. David Grynspan, MD ${ }^{1}$ \\ ${ }^{1}$ Faculty of Medicine, University of Ottawa
}

When I teach I try to address the people who feel most alienated.

William Carlos Williams was a pediatrician and a poet often thought of as one of the early modernists. His poem "Between Walls" is a famous example of the unsentimental concise sharpness that characterized (some of) modern poetry [1]. It is about looking for a glint of hope or meaning in the sterility of the modern hospital and finding some beauty in the imagery of the broken pieces of a green bottle. This arbitrarily assigned aestheticto strewn discarded shards - replaces the romantic subjectivity that the modernists feel that we can't have anymore. Their view is that we have been too overexposed and desensitized to accept conventional symbols.

An important part of medical education is being present with students on a journey of desensitization and trying to provide an anchor for the retention of "humanity", not that I know exactly what that is. I am a pediatric pathologist and my job involves doing autopsies on deceased children. In my training, I felt that to survive I would need to learn to find beauty in the terrible. This was not a modern sentiment. I was never fully modern. I wanted to find salvation in suffering not just discover accidental colors. I saw hints of this in the assignment of names from Greek Mythology in the naming of fetal malformation: Cyclopia, Sirenomelia: the epic battle between mortals and not entirely insurmountable gods.

Modern medicine emphasizes objectivity and the dispassionate gaze. Critics such as Foucault have pointed out that medicine itself is subjective and its beliefs and constructs are predicated more on the prevailing normative culture than objective truths. That has been my experience.

Money is also a big part of it. There is a lot that is commodified, commercialized and corporate. Do we really want more longevity at the price of our spirits and voices? How can there be real meaning when we all sound like mid-level bureaucrats? In this new lingo, we speak litany to litany not heart to heart, so what words do we have to discuss compassion?
Modern poetry is subversive because it puts presence (and then form) over content and thus questions what is valuable, and because it takes authority out of authorship and tells us all to find meaning together. All poetry and perhaps all art (modern or ancient) is subversive because it dwells in possibilities when possibilities have been exiled.

The most widely read Canadian Post-Modern poem is Christian Bok's Eunoia [2]. He chose that title because it is one of the few English words that have all vowels in it. It means "beautiful thinking" and in Greek Philosophy was described as the state of mind one has to be in to make a friend. Artists converge in communities of the disenfranchised and find this state of mind.

I use poetry in my teaching because, in the end, all communities are communities of the disenfranchised and all pedagogy is pedagogy of the misunderstood.

\section{REFERENCES}

1. Williams CW. "Between Walls" from The Collected Poems of William Carlos Williams, Volume I, 1909-1939, edited by Christopher MacGowan. New York, NY: New Directions Publishing Corporation; 1988.

2. Bok C. Eunoia. Toronto, ON: Coach House Books; 2001. 